\title{
A review on effects of ceramic tile waste as partial replacement of coarse
} aggregate on geopolymer paver block.

\section{Una revisión sobre los efectos de los residuos de baldosas cerámicas como reemplazo parcial de agregado grueso en adoquines de geopolímero}

\author{
Sweda Sara Philip, Archana C P \\ Department of Civil Engineering \\ Toc H Institute of Science and Technology, Ernakulam (Kerala), India \\ Corresponding author mail id: swedasera@gmail.com
}

\begin{abstract}
Paver blocks are used in many areas like street road and other construction places. Due to rapid infrastructure development the use of cement is increasing. Cement emits large amount of carbon dioxide $\left(\mathrm{CO}_{2}\right)$ and this leads to global warming. Today researches on waste management lead to an eco-friendly product called geopolymer mortar and concrete. To support the development of pavement construction in the civil engineering industry, a new approach to predicting the performance of the geopolymer paver block (GPB) has been proposed. A huge quantity of ceramic waste is generated during processing, transportation and handling. To reduce this waste disposal, ceramic waste can be used as an alternative material to natural coarse aggregate. Fly ash and Ground Granulated Blast-furnace Slag (GGBS) are activated using alkaline solution such as sodium silicate and sodium hydroxide to get cementitious binder. There are various paper and research works based on natural coarse aggregate replaced by various percentages of other industrial waste material and cement replaced by various percentage of other waste material and it is found that there is increase in strength, durability and reduction in cost and utilization of waste material. Various waste material can be used for improving strength of paver block. The primary objective of this review is to understand the properties as well as economical and environmental benefits of GPB using ceramic tile waste corresponding to M40 grade (16M) based on earlier researches. From the mix designed, 25\% Fly ash and 75\% GGBS shows optimum mix. The review work also focus on selection of various percentages of ceramic tile waste for replacing natural coarse aggregate.
\end{abstract}

Key Words: Geopolymer Paver Block, Fly Ash, GGBS, Cementitious binder, Alkaline solution, Ceramic tile waste 
Sustainability, Agri, Food and Environmental Research, (ISSN: 0719-3726), 10(X), 2022: http://dx.doi.org/

\section{RESUMEN}

Los bloques de adoquines se utilizan en muchas áreas como calles y otros lugares de construcción. Debido al rápido desarrollo de la infraestructura, el uso de cemento está aumentando. El cemento emite una gran cantidad de dióxido de carbono (CO2) y esto conduce al calentamiento global. Hoy en día, las investigaciones sobre la gestión de residuos conducen a un producto ecológico llamado mortero y hormigón de geopolímero. Para respaldar el desarrollo de la construcción de pavimentos en la industria de la ingeniería civil, se ha propuesto un nuevo enfoque para predecir el rendimiento del bloque de adoquines de geopolímero (GPB). Se genera una gran cantidad de residuos cerámicos durante el procesamiento, transporte y manipulación. Para reducir esta eliminación de desechos, los desechos de cerámica se pueden utilizar como material alternativo al agregado grueso natural. Las cenizas volantes y la escoria de alto horno granulada molida (GGBS) se activan utilizando una solución alcalina como el silicato de sodio y el hidróxido de sodio para obtener un aglutinante cementoso. Existen varios trabajos de papel e investigación basados en áridos gruesos naturales reemplazados por varios porcentajes de otros materiales de desecho industriales y cemento reemplazado por varios porcentajes de otros materiales de desecho y se encuentra que hay aumento en la resistencia, durabilidad y reducción en el costo y la utilización de Material de desecho. Se pueden usar varios materiales de desecho para mejorar la resistencia del bloque de adoquines. El objetivo principal de esta revisión es comprender las propiedades, así como los beneficios económicos y ambientales de GPB utilizando residuos de baldosas cerámicas correspondientes al grado M40 (16M) según investigaciones anteriores. De la mezcla diseñada, $25 \%$ de cenizas volantes y $75 \%$ de GGBS muestra una mezcla óptima. El trabajo de revisión también se centra en la selección de varios porcentajes de residuos de baldosas de cerámica para reemplazar el agregado grueso natural.

Palabras clave: bloque de adoquines de geopolimero, cenizas volantes, GGBS, aglutinante de cemento, solución alcalina, residuos de baldosas de cerámica

\section{INTRODUCTION}

Concrete is the world's most adaptable, durable and reliable construction material. Large amount of energy is used for the cement production. Therefore, seeking an alternative material to the existing most expensive, most resource-consuming portland cement is inevitable. Geopolymer concrete is an innovative material that is made by reacting aluminate and silicate bearing materials with alkali activator. Commonly, waste materials such as fly ash or slag from iron and metal production are used; this will lead to pollution free environment. Interlocking Concrete Block Pavement (ICBP) technology has been introduced in India in construction for requirements like footpaths, parking areas etc. 
Sustainability, Agri, Food and Environmental Research, (ISSN: 0719-3726), 10(X), 2022: http://dx.doi.org/

Nowadays, sources of natural aggregates are in the process of depletion and their extraction also has harmful consequences for the environment. For these reasons, it is important to optimize the consumption of natural aggregates as well as to enhance their replacement by other alternative sources. One of the method is the use of ceramic tile waste in concrete. The composition and performance between ceramic tile and natural coarse aggregate is comparable. The usage of waste materials in concrete production is very much helpful to reach the goal of the sustainable construction. To reduce the consumption of natural aggregates, waste ceramic tile or crushed tiles as coarse aggregates can be used. M35 to M45 grade concrete are used for medium traffic roads as per IS 15658:2006 (Thunuguntla C.S et.al, 2018). There are several studies conducted on the utilization of waste materials or using these products as binding material. Geopolymer concrete is very helpful in providing a new approach towards sustainability. This makes the geopolymer concrete a substitute for traditional concrete.

\section{STUDIES ON ALKALI ACTIVATED SLAG CONCRETE}

Alkali-Activated slag (AAS) has a great potential for using as industrial byproducts. The production of AAS concretes is associated with low energy consumption and low $\mathrm{CO}_{2}$ emission. The effects of sodium hydroxide and sodium silicate solutions on the properties of fly ash (FA) - granulated blast furnace slag (GBFS) with constant liquid alkaline to binder ratio of 0.60 has better results. There are Three types of geopolymer pastes: FA paste, FA + GBFS paste and GBFS paste and three types of alkaline solutions: sodium hydroxide solution (NH), sodium silicate solution (NS), and sodium hydroxide + sodium silicate solution (NHNS) were used. From the study it was concluded that, the FA paste contains amorphous sodium aluminosilicate hydrate (NASH) gel and a few crystalline phases of the remain of ash. The compressive strength of geopolymer paste increases due to the presence of GBFS content and formation of additional CSH. For the GBFS paste, the presence of silicate enhanced the strength development and thus pastes containing NS solution performed better. The Relatively high 28-day compressive strengths of 171.7 and 173.0 MPa were obtained for GBFS pastes with NHNS and NS solutions, respectively. (Ngernkham T.P et.al, 2015)

The durability performance of AASC, which involves sorptivity, acid attack (upto 56 days) due to sulphates, chlorides and nitrates, has been tested in various tests. $\mathrm{NaOH}$ concentration was found to be the most influential parameter of AASC's mechanical and durability characteristics. AASC mixes with higher $\mathrm{NaOH}$ concentration exhibited better resistance to acid attack as compared to mixes with lower $\mathrm{NaOH}$ concentration, which may be attributed to high alkalinity and strong porous structure of concrete. (Thunuguntla C.S et.al, 2018) 
Sustainability, Agri, Food and Environmental Research, (ISSN: 0719-3726), 10(X), 2022: http://dx.doi.org/

The silicon and aluminium oxides in the low -calcium flyash reacts with the alkaline liquid to form the geopolymer paste that binds the loose coarse and fine aggregates and other unreacted materials to form the geopolymer concrete. The compressive strength and workability of geopolymer concrete are influenced by the proportions and properties of the constituent materials that make the geopolymer paste. The water/binder ratio $\&$ alkaline liquid/flyash ratio are the governing factors in geopolymer mix design for various grades. The water/binder ratios of $0.27,0.21 \& 0.158$ and alkaline liquid to flyash ratios of $0.50,0.40$ $\& 0.35$ are suggested for $\mathrm{G} 20, \mathrm{G} 40$ \& G60 respectively which indicates improvement in compressive strength of geopolymer concrete can be achieved by decreasing water binder ratio. The decrease in water content favors the formation of geopolymerization process, which demands in the increase in concentration of sodium hydroxide and sodium silicate. Hence increase in concentration of $\mathrm{NaOH}$ results in increase of compressive strength. 28 days compressive strength for OPC conventional concrete for M20, M40 \& M60 is 27.5MPa, 48.8 $\mathrm{MPa} \& 68.6 \mathrm{MPa}$ respectively, whereas for geopolymer heat cured specimens at $600^{\circ} \mathrm{C}$, for $24 \mathrm{hrs}$ is $30.4 \mathrm{MPa}, 50.00 \mathrm{MPa} \& 71.2 \mathrm{MPa}$ for $\mathrm{G} 20, \mathrm{G} 40$ \& G60 respectively. Hence it is recommended $8 \mathrm{M}, 16 \mathrm{M} \& 16 \mathrm{M}$ concentrations for Low, medium and higher grades respectively. (Dr.M.Potharaju et.al, 2013)

Ground granulated blast-furnace slag (GGBS) cement is substituted by AA GGBS binder which results in reduction of $\mathrm{CO}_{2}$ for secondary precast concrete items. For various types of concrete, the performance efficiency metrics for the binder were calculated. The $\mathrm{CO}_{2}$ emission of concrete increases its compressive strength, showing that the contribution of the binder to the overall $\mathrm{CO}_{2}$ footprint is more visible in OPC-based concrete than in $\mathrm{AA}$ concrete. When the compressive strength is above $40 \mathrm{MPa}$, the $\mathrm{CO}_{2}$ emissions of OPC + SCM (Supplementary Cementitious Materials) concrete are around 80 percent of those of OPC concrete. On the other hand, the $\mathrm{CO}_{2}$ emission reduction rate of $\mathrm{AA}$ concrete relative to OPC concrete commonly ranges between 55 and $75 \%$, although the $\mathrm{CO}_{2}$ reduction of $\mathrm{AA}$ concrete is somewhat hooked in to the sort, concentration, and dosage of the added alkali activators. (Yang K.H et.al, 2013)

\section{GEOPOLYMER PAVER BLOCK (GPB)}

Various empirical models were developed to predict the performance of the GPB samples through the verification of the water absorption and compressive strength. Studies were conducted to produce some compositions of geopolymer paving block (GPB) using different ratios of $\mathrm{NaOH} / \mathrm{Na}_{2} \mathrm{SiO}_{3}$ combined with fly ash. The results showed that an optimum performance of GPB sample is predicted for the $\mathrm{NaOH} / \mathrm{Na}_{2} \mathrm{SiO}_{3}$ ratio range of 0.4 to 0.67 and it was verified at 28 days of the GPB age. The hardness of GPB sample increases rapidly by using a high concentration of $\mathrm{NaOH}$ it significantly increases the compressive strength of paver block. Study concluded that, the water absorption of GPB sample used 
Sustainability, Agri, Food and Environmental Research, (ISSN: 0719-3726), 10(X), 2022: http://dx.doi.org/

$\mathrm{NaOH} / \mathrm{Na}_{2}-\mathrm{SiO}_{3}$ ratio of 0.4 has the lowest value of $2.93 \%$ at 28 days of the GPB age. The maximum compressive strength of $32.45 \mathrm{MPa}$ for the suggested GPB sample of highest workability can be verified at 28 days of the GPB age by using the $\mathrm{Na}_{2} \mathrm{SiO}_{3}$ portion of 2.5 . The new empirical models of predicting the GPB performance have been suggested to contribute to the development of pavement construction to hardening the parking lot for many cities of Indonesia in the future. (Jonbi Jonbi et.al, 2020)

An experimental research was conducted on geopolymer mortar and concrete with industrial products such as fly ash and GGBS using alkaline solution to understand the properties of geopolymer concrete, as well as the economic, technical and environmental benefits. In this analysis, it was observed that both geopolymer concrete and mortar are prepared to be healed at ambient temperature and tested for compressive strength. From the research it was concluded that, from both strength and durability considerations, GPC are good construction material. Geopolymer concrete has significant potential to be a material for the future, because it is not only environmentally sustainable, but also has outstanding mechanical properties. Due to the lower internal energy (almost 20 percent to 30 percent) and lower $\mathrm{CO}_{2}$ emission content of geopolymer-based composite ingredients compared to traditional PPC concretes, modern composites can be considered more environmentally friendly and thus need to be produced and promoted to be useful in practical applications. (Devaki. R et.al, 2017)

Geopolymer concrete paver block with the M40 grade mix based on low calcium fly ash have excellent compressive strength within a short time (3 days) without water treatment and are ideal for practical applications. The ratio between alkaline liquid and flying ash was 0.35 and the ratio of sodium silicate to sodium hydroxide is 2.5 . The sodium hydroxide concentration was $10 \mathrm{M}$. Geopolymer concrete is an excellent alternative to Portland concrete cement. Geopolymer concrete can be used effectively for the development of precast concrete paver blocks (Murugan R.B et.al, 2016). Geopolymer concrete pavers based on low calcium fly ash have excellent compressive strength within a short time (3 days) and are suitable for functional applications. For GPC, there is no need for water curing, which can save manufacturing units a lot of curing time and space. On the 7th day, the GPC paver block reached greater strength than the OPC pavers at 28 days, i.e. $49.32 \mathrm{~N} / \mathrm{mm}^{2}$ for OPC and $53.12 \mathrm{~N} / \mathrm{mm}^{2}$ for GPC. The GPC paver block variance is very small at 7th day strength to 28 day strength. So it can be concluded that the GPC paver attain early strength than OPC pavers.(Basil M Mali et.al, 2016)

Geopolymer concrete in precast concrete paver blocks of base propotion 1:1.2:2 with a target strength of $47 \mathrm{MPa}$ was developed which is suitable for highway. Water to cement ratio was 0.35 . Ratio of alkaline liquid to fly ash was taken as 0.35 . Ratio of sodium silicate to sodium hydroxide was taken as 2.5. The concentration of sodium hydroxide was varied from $8 \mathrm{M}$ to $12 \mathrm{M}$. Super plasticizer about $2.65 \mathrm{~kg} / \mathrm{m}^{3}$ may be added to get the required 
Sustainability, Agri, Food and Environmental Research, (ISSN: 0719-3726), 10(X), 2022: http://dx.doi.org/

workability. The Geopolymer concrete can be effectively used for manufacture of precast concrete paver blocks. GPC paver block have high compressive strength for the same mix proportion and high strength to gain. This can save lot of curing time and space at manufacturing units. GPC paver blocks outperform OPC paver blocks under freezing and thawing conditions. (Aaron Darius Vaz et.al, 2012)

\section{CERAMIC TILE AS COARSE AGGREGATE IN CONCRETE}

The utilization of ceramic materials is increasing day by day in the form of tiles, sanitary fittings etc and among that, a huge quantity of ceramic materials convert into wastage during its processing, transporting and fixing due to its brittle nature. Therefore, using these wastes in concrete production it could be an effective measure in maintaining the environment cleans and improving the properties of concrete. The crushed waste ceramic tiles were used in concrete as a replacement for natural coarse aggregates with $10 \%, 20 \%, 30 \%, 40 \%$ and $50 \%$ of substitution, the optimum value of waste ceramic tile to be used within the concrete mix with a water/cement ratio of 0.5 was determined as about $30 \%$. The compressive and flexural strength of optimum percentage replacement concrete was found $5.43 \%$ and $32.2 \%$ higher than reference concrete respectively. The optimum value of waste ceramic tile to be used within the concrete mix with a water/cement ratio of 0.5 was determined as about 30\%. The compressive and flexural strength of optimum concrete was found $5.43 \%$ and $32.2 \%$ higher than reference concrete respectively. Flexural strength of Optimal Waste Ceramic Concrete was $32.2 \%$ higher. The optimal case of using waste ceramic tiles as coarse aggregates is found to be 10 to 30 percent. (Md Daniyal et.al, 2015)

Ceramic waste replacement at intervals of $25 \%$ was comparatively evaluated for $1: 2: 4 \mathrm{mix}$ of $150 \times 150 \times 150 \mathrm{~mm}$ cube specimens, while tensile strength was investigated using $150 \times 300 \mathrm{~mm}$ cylinder specimens. Test results show that workability, density, compressive and flexural strength of concrete decreased with increase in ceramic waste content. The compressive strength values at 90 days curing age for $25 \%, 50 \%$ and $75 \%$ replacement levels were $21.78 \mathrm{~N} / \mathrm{mm}^{2}, 19.85 \mathrm{~N} / \mathrm{mm}^{2}$ and $17.85 \mathrm{~N} / \mathrm{mm}^{2}$ respectively. The decrease in density and strength was due to ceramic waste being lighter and more porous than normal coarse aggregate. Tensile strength of concrete with ceramic waste decline gradually from $8.39 \mathrm{~N} / \mathrm{mm}^{2}$ to $6.13 \mathrm{~N} / \mathrm{mm}^{2}$ for the control and $75 \%$ replacement samples respectively. This could be attributed to the water absorption capacity and external porcelain nature of the waste material. A production cost savings of $10.7 \%$ for $1: 2: 4$ concrete mix was noted at 75\% replacement level. Ceramic waste could be used for both structural and non-structural works and recommends that beyond $75 \%$ replacement level; ceramic waste material should not be used in concrete structures where strength is the major consideration. The use of ceramic waste in concrete is an effective way to reducing 
Sustainability, Agri, Food and Environmental Research, (ISSN: 0719-3726), 10(X), 2022: http://dx.doi.org/

the costs of concrete and keeping the environment clean through efficient management of waste and decrease in the use of normal coarse aggregate in concrete production. (Ikponmwosa E.E et.al, 2017)

The structural impact of Ceramic Tile Waste (CTW) as a partial replacement of coarse aggregates in the manufacture of concrete was studied. Different concrete samples were produced with a $10 \%$ step content of $0-40 \%$ as a partial replacement of granite with CTW and $100 \%$ CTW as coarse aggregates. On coarse aggregates, fresh and hardened concrete, tests were conducted which results that the workability of the mixes increased with increased percentage of CTW content up to $30 \%$ and for more than $30 \%$ workability decreased. There was slight decrease in the compressive strength of the test samples with increase in the CTW content having a minimum permissible value of $20.03 \mathrm{~N} / \mathrm{mm}^{2}$ at 28 day for $40 \%$ inclusion of CTW. Aggregate impact value of the granite is lower compared with that of Ceramic Tiles Waste which implies it was tougher than CTW. The slump test showed that the concrete becomes less workable as the CTW percentage increases beyond $20 \%$. Compacting factor increases with increase in the percentage of CTW up to $20 \%$ above which the value began to fall. The compressive strength of concrete reduced with the increase in percentage of CTW replacement. Use of CWT to replace granite as coarse aggregates up to $30 \%$ in the production of concrete is established. (Ajamu S.O et.al, 2018) An environmentally sustainable solution must be adopted to dispose waste materials. It is possible to use the floor tile as aggregates in the production of concrete in order to reuse. Concrete produced from floor tile waste has some more better physical and mechanical characteristics than conventional concrete. The best water absorption value was displayed by Floor Tile waste aggregate concrete i.e; 1.394\%. Ceramic waste can be transformed into useful crushed stone aggregate instead of natural coarse aggregate. The properties of ceramic waste coarse aggregate are within the range of the values of concrete making with natural aggregates. (E.Gunay et.al, 2016)

\section{CONCLUSION}

Interlocking Concrete Block Pavement (ICBP) has been used over traditional pavements in many places as a specialised problem-solving method, which is less durable due to many operational and environmental constraints. Replacing high volumes of supplementary cement materials (SCMs) with Portland cement lowers $\mathrm{CO}_{2}$ emissions by around 51 to 75 percent. Geopolymer concrete using Ceramic tile waste as coarse aggregate shows good potential as an alternative material to traditional Portland cement concrete from the studies. Fly Ash and GGBS showed higher strength properties and while the GGBS percentage is increased the strength increases. From the mix designed $25 \%$ Fly ash and $75 \%$ GGBS shows optimum mix and studies shows that $25 \%$ Fly ash and $75 \%$ GGBS replacement is good for paver block. Geopolymer ceramic tile concrete has various 
Sustainability, Agri, Food and Environmental Research, (ISSN: 0719-3726), 10(X), 2022:

http://dx.doi.org/

advantages over OPC, such as low impact on the environment, high strength and rapid strength gain. In the context of reducing $\mathrm{CO}_{2}$ emissions, the one prospect currently practiced is replacing Portland cement with high volumes of supplementary cementitious materials (SCMs). In the manufacture of concrete, efficient use of locally accessible SCMs such as fly ash and ground granulated blast furnace slag (GGBFS) decreases the burden on landfills and environmental pollution. Using high $\mathrm{NaOH}$ concentrations in the activator, the hardness of the Geopolymer paver block sample increases rapidly. The crushed waste ceramic tiles were used in concrete as a replacement for natural coarse aggregates with $10 \%, 20 \%, 30 \%, 40 \%$ and $50 \%$ of substitution. Thus, geopolymer ceramic tile paver block is good alternative to cement concrete paver block.

\section{REFERENCES}

Aaron Darius Vaz, Amar S.M , Donal Nixon D'Souza, Noothan Kaliveer and Satish K.T (2012) 'Geopolymer Paver Blocks', Proc. of Int. Conf. on Advances in Civil Engineering, 173-178.

Ajamu S.O. ,Ogunyemi E.S and Oluremi J. R. (2018) 'Impact of Replacement of Coarse Aggregates with Ceramic Tile Waste on the Strength Characteristics of Concrete', Journal of Research Information in Civil Engineering, 2228-2244

Basil M Mali, Renjan Abraham (2016) 'Study On Geopolymer Concrete Used For Paving Blocks', International Journal of Innovative Research in Advanced Engineering (IJIRAE), 62-66.

Devaki. R, Dinesh. S \& Srimathi. S (2017) 'Experimental investigation on paver block using geopolymer concrete', International Journal of Engineering Research and Modern Education, 47-50.

Dr.M.Potharaju, Kolli Ramujee (2013) Development of mix design for low calcium based geopolymer concrete in low, medium and higher grades -Indian scenario, Journal of Civil Engineering and Technology (JCIET),1(1), 15-25.

E.Gunay, M.Kara,, S.T.Yildirim, S.Yilmaz and Y.Tabak (2016) 'Ceramic tile waste as a waste management solution for concrete', 3rd International Conference on Industrial and Hazardous Waste Management, 1-8.

Ikponmwosa E.E and Ehikhuenmen S.O (2017) 'The effect of ceramic waste as coarse aggregate on strength properties of concrete', 691-696 
Sustainability, Agri, Food and Environmental Research, (ISSN: 0719-3726), 10(X), 2022:

http://dx.doi.org/

Jonbi Jonbi, Mohamad Ali Fulazzaky (2020) 'Modeling the water absorption and compressive strength of geopolymer paving block: An empirical approach', Measurement, 1-7

Md Daniyal, Shakeel Ahmad (2015) 'Application of Waste Ceramic Tile Aggregates in Concrete', International Journal of Innovative Research in Science, Engineering and Technology, 1280-1285

Murugan R.B, Natarajan C, Chen S, (2016) 'Material development for a sustainable precast concrete block pavement', Journal of traffic and transportation engineering, 483 491.

Ngernkham T.P, Maegawa A, Mishima N and Hatanaka S (2015) 'Effects of sodium hydroxide and sodium silicate solutions on compressive and shear bond strengths of FA-GBFS geopolymer', Construction and Building Materials, 01-08.

Thunuguntla C.S and Gunneswara Rao T.D (2018) 'Effect of mix design parameters on mechanical and durability properties of alkali activated slag concrete', Construction and Building Materials, $173-188$.

Yang K.H, Song J.K, Song K.I, (2013) 'Assessment of $\mathrm{CO}_{2}$ reduction of alkali-activated concrete', Journal of Cleaner Production, 265 - 272.

IS 15658: 2006 Precast concrete blocks for paving-specification.

IS 2386 (part III): 1963 Indian standard Methods of test for aggregates for concrete.

Received: $30^{\text {th }}$ January 2021; Accepted: $11^{\text {th }}$ March 2021; First distribution: 01th April 2021 